\title{
RESIDUAL EFFECTS OF DIFFERENT MANURES AND FERTILIZERS APPLIED TO PRECEDING POTATO CROP ON SUCCEEDING MUNG BEAN (Vigna radiate L.) CROP IN POTATO-MUNG BEAN-RICE CROPPING PATTERN
}

\author{
S. Bilkis, M.R. Islam", M. Jahiruddin, M. M. Rahman and T.S. Hoque \\ Department of Soil Science, Bangladesh Agricultural University, Mymensingh-2202, Bangladesh
}

\begin{abstract}
The present study was done at Bangladesh Agricultural University farm to evaluate the field performances of different types of manures viz. cowdung (CD), cowdung slurry (CD slurry), trichocompost (TC), vermicompost (VC), poultry manure (PM) and poultry manure slurry (PM slurry) with chemical fertilizers in the potato-mungbean-T. aman rice cropping pattern during 2011-12 and 2012-13. The experiment was laid out in a randomized complete block design, with three replications and eight treatments including $\mathrm{T}_{1}$ (Control), $\mathrm{T}_{2}$ [HYG based $100 \%$ chemical fertilizer (CF)], $T_{3}$ [CD + CF (IPNS basis)], $T_{4}$ [CD slurry + CF (IPNS basis)], $T_{5}$ [PM + CF (IPNS basis)], $\mathrm{T}_{6}$ [PM slurry + CF (IPNS basis)], $\mathrm{T}_{7}$ [TC + CF (IPNS basis)] and $\mathrm{T}_{8}$ [VC + CF (IPNS basis)]. Trichocompost $+\mathrm{CF}$ and vermicompost $+\mathrm{CF}$ containing treatments produced higher crop yield followed by poultry manure slurry and cowdung slurry. Integrated use of manures and fertilizers gave on an average $6.7-33.7 \%, 8.3-33.8 \%$ and $2.9-18.3 \%$ yield increase in potato, mungbean and $\mathrm{T}$. aman rice, respectively over sole application of chemical fertilizers (data not shown). Use of IPNS improved nutrient content and uptake of mungbean. The present study thus indicates that use of manure, especially trichocompost, vermicompost, PM slurry and CD slurry integrated with chemical fertilizers would help increase crop yield and improve soil fertility. However, Trichocompost + CF was the best option in this regard.
\end{abstract}

Keywords: Cowdung, poultry manure, trichocompost, vermicompost, slurry, mungbean, crop yield, soil fertility

\section{INTRODUCTION}

Agriculture is the mainstay of economy in terms of contribution to GDP as well as improvement of livelihood of majority people in Bangladesh. Regular practicing of

\footnotetext{
* Corresponding Author email: mrislam69@yahoo.com
} 
cereal-cereal cropping pattern on the same land over the years has increased soil fertility depletion and questions raised for its sustainability (Prasad, 2005). The ricerice cropping pattern, therefore, causes a considerable depletion of soil nutrients threatening long-term productivity. Sustainable crop production in Bangladesh through improvement of cropping pattern in rice based cropping system is regarded as increasingly important in national issues such as food security, poverty alleviation, land degradation and pollution control (Rahman et al., 2018). Therefore, it is crucial to make efforts to find out alternative cropping patterns. Mungbean (Vigna radiata L.) is an important legume or pulse crop in Asia, which can be a major component in different cropping systems. Short lived leguminous mungbean plants can be grown in various cropping patterns because they have the ability to adapt environmental stresses like drought, low soil fertility etc (Bourgault et al., 2010) and the inclusion of a grain legume in the cropping pattern will supply substantial amount of biomass and $\mathrm{N}$ to soil and thus improve soil fertility and crop productivity on sustainable basis (Ali et al., 2012).

Over the last few decades, enormous pressure has been exerted on the land resources of Bangladesh to meet the demand of its vast population for food and fuel. Due to intensification of agricultural land, use of modern crop varieties, soil fertility has declined and deficiency of nutrient elements such as $\mathrm{N}, \mathrm{P}, \mathrm{K}, \mathrm{S}, \mathrm{Zn}$ and $\mathrm{B}$ has arisen (FRG, 2012). There is no doubt that chemical fertilizers are playing a vital role to meet the nutrient requirement of crops and thereby increase their production. However, recently the non-judicious use of chemical fertilizers is posing both economic and ecological problems, which are often difficult to face, particularly in developing countries (Sutton et al., 2011). The cost of chemical fertilizers is high but the organic manure is easily available and low cost. Therefore, smallholder farmers have shift their attention from chemical alone agriculture to integrated nutrient management strategy which utilizes both organic and inorganic nutrients forms (Singh et al., 2010). Since the nutrient turnover in soil-plant, system is considerably high in intensive farming; neither the chemical fertilizers nor the organic and biological sources alone can achieve sustainable productivity. Only organic sources cannot maintain and synchronize the nutrient supply demand to the growing plant due to lesser quantity of mineral nutrients or time needed for their mineralization to release nutrients for plant uptake. Organic matter acts as a reservoir of plant nutrients, chiefly N, P and S and it improves cation exchange capacity of soil (Brady and Weil, 2012) and therefore important for soil rejuvenation (Jeptoo et al., 2013). Integrated use of composted organic manures with chemical fertilizers could be more effective, economical and sustainable for both agriculture and environment.

In a cropping pattern, the preceding crops and the inputs such as fertilizers, manures, residues etc. applied therein, influence the responses of succeeding crops highly. The present study was therefore undertaken to assess the residual effects of organic manures applied to the first crop, nutrient status and economical status of succeeding mung bean in the potato-mung bean-rice cropping pattern. The present study was 
initiated to assess the residual effect of different types of manure applied to proceeding potato crop on yield, nutrient uptake and economic benefits of succeeding crop of mung bean in the potato-mung-bean-rice cropping pattern. It was also found that growing a short duration mung bean after potato and incorporating of its residue in succeeding rice made potato-rice cropping pattern more productive, remunerative and recuperative soil than traditional potato-rice cropping pattern.

\section{MATERIALS AND METHODS}

\section{Experimental site and soil characters of the location}

The experiment was conducted at the Soil Science Field Laboratory of Bangladesh Agricultural University (BAU), Mymensingh, Bangladesh for two consecutive years, 2011-12 and 2012-13, respectively. The soil belongs to Sonatala series under the AEZ-9 (Old Brahmaputra Floodplain) (UNDP and FAO, 1988). The soil was silt loam in texture having $\mathrm{pH} 6.29$, organic matter content $1.85 \%$, total $\mathrm{N} 0.124 \%$, available P $3.96 \mathrm{ppm}$, exchangeable K $0.11 \mathrm{me} \%$, available S $11.9 \mathrm{ppm}$ and CEC $12.5 \mathrm{me} \%$.

\section{Experimental design, treatments and crops}

The experiment was laid out in a randomized complete block design, with three replications for first year cycle. The experiment consisted of eight treatments viz. $\mathrm{T}_{1}=$ Control (no manure or fertilizer), $\mathrm{T}_{2}=100 \%$ chemical fertilizer $(\mathrm{CF}), \mathrm{T}_{3}=\mathrm{CD}+\mathrm{CF}$, $\mathrm{T}_{4}=\mathrm{CD}$ slurry $+\mathrm{CF}, \mathrm{T}_{5}=\mathrm{PM}+\mathrm{CF}, \mathrm{T}_{6}=\mathrm{PM}$ slurry $+\mathrm{CF}, \mathrm{T}_{7}=\mathrm{TC}+\mathrm{CF}, \mathrm{T}_{8}=\mathrm{VC}+\mathrm{CF}$. The doses of N-P-K-S were 135-25-95-12 kg/ha for the first crop (potato). The residual effect of manures and fertilizers was evaluated on succeeding mung bean crop. Diamont was used as the variety every year in the experimental plots in the mid-November and harvested in the mid-February. After harvesting of potato, the seeds of mungbean (cv. Binamung 8) were sown on 24 March @ $30 \mathrm{~kg} \mathrm{ha}^{-1}$ and harvested at the end of June.

\section{Manures and fertilizers application}

Poultry manure and PM slurry were applied @ $5 \mathrm{t} \mathrm{ha}^{-1}$ where as the rest of the manures (CD, CD slurry, TC and VC) were applied @ $3 \mathrm{t} \mathrm{ha}^{-1}$. Potato received full quantities of urea, TSP, MoP and gypsum during land preparation while rotten cowdung, decomposed poultry manure and compost were applied 7 days before transplanting. The rates of ffertilizers for mung bean was calculated and rationalized considering residual effect of plant nutrient (except $\mathrm{N}$ ) applied to previous crop (potato) (FRG, 2012). Manures were applied to the first crop (potato) and their residual effects were evaluated on the second crop (mung bean). This was repeated for the second year to complete two cropping cycles.

\section{Intercultural operations}

Intercultural operations such as weeding, thinning and irrigation were done as and when required. 


\section{Data collection}

At maturity, the crop was harvested and the different data were recorded. Seed and grain yield was recorded on $14 \%$ moisture basis and stover yield at sundry basis.

\section{Chemical analysis of plant and soil samples}

The seed and stover samples were collected, dried and ground for analysis of N, P, K and $\mathrm{S}$ contents. The ground plant materials were stored in paperbags separately and placed in a desiccators. The total $\mathrm{N}$, available $\mathrm{P}$, exchangeable $\mathrm{K}$ and available $\mathrm{S}$ of plant samples were determined following semi-micro Kjeldahl method, modified Olsen method, $\mathrm{NH}_{4} \mathrm{OAc}$ extraction method and $\mathrm{CaCl}_{2}$ extraction method, respectively. After chemical analysis of seed and stover samples of mung bean, the nutrient uptake was calculated from the nutrient content and yield of the crop using the following formula:

$\mathrm{TU}=\mathrm{NC} \times \mathrm{Y} / 100$

where, $\mathrm{TU}=$ total nutrient uptake $\left(\mathrm{kg} \mathrm{ha}^{-1}\right), \mathrm{NC}=$ nutrient concentration $(\%)$, and $\mathrm{Y}=$ yield $\left(\mathrm{kg} \mathrm{ha}^{-1}\right)$

\section{Statistical analysis}

Statistical analysis of the data was done by using computer based statistical program Mstat-C (Michigan State University, East Lansing, MI, USA) following the basic principles stated by Gomez and Gomez (1984). Significant effects of treatments were determined by analysis of variance (ANOVA) and Duncan's Multiple Range Test (DMRT) evaluated the mean comparisons of the treatments at 5\% level of significance.

\section{Yield components}

During both years of this experiment, all combination of manures significantly increased the yield components viz. number of pods plant ${ }^{-1}$, seeds $\operatorname{pod}^{-1}$ over the control (Table 1). The number of pods plant ${ }^{-1}$ varied from 11.1 to 21.3 in 2012 while it ranged from 10.9 to 17.5 in 2013 . In both the years, the highest number of pods plant ${ }^{-1}$ was recorded in $\mathrm{T}_{7}$ treatment $(\mathrm{TC}+\mathrm{CF})$ and the lowest in control $\left(\mathrm{T}_{1}\right)$. In year 2012 , the highest value of number of pods plant ${ }^{-1}$ was statistically similar with $\mathrm{T}_{5}$ $(\mathrm{PM}+\mathrm{CF}), \mathrm{T}_{6}(\mathrm{PM}$ slurry $+\mathrm{CF})$ and $\mathrm{T}_{8}(\mathrm{VC}+\mathrm{CF})$ treatments and with $\mathrm{T}_{3}(\mathrm{CD}+$ $\mathrm{CF}), \mathrm{T}_{4}(\mathrm{CD}$ slurry $+\mathrm{CF}), \mathrm{T}_{5}$ and $\mathrm{T}_{8}$ in the year 2013. Generally, effect of manure containing treatments $\left(\mathrm{T}_{3}-\mathrm{T}_{8}\right)$ had better performance on number of pods plant ${ }^{-1}$ compared to exclusive fertilizer treatment $\left(\mathrm{T}_{2}\right)$. On the other hand, the number of seeds pod ${ }^{-1}$ ranged from 9.0 to 11.1 in 2012 and 9.2 to 12.2 in 2013. In both the years, $\mathrm{T}_{7}$ produced the maximum number of seeds pod $^{-1}$ while control produced the lowest. The highest number of pods plant ${ }^{-1}$ was statistically identical with all the treatments except control in the first year and with $\mathrm{T}_{4}$ and $\mathrm{T}_{6}$ in the second year. This might be 
due to the release of more nutrients from manures in the second year. Similar results were shown by Davari et al. (2012), Prajapati et al. (2016) and Meena et al. (2016).

Table 1. Integrated effects manure and fertilizers on pod number plant $^{-1}$, seed number $\operatorname{pod}^{-1}$ and 1000-seed weight of mungbean (Binamoog-8) in the potato - mungbean $-\mathrm{T}$. aman rice cropping pattern

\begin{tabular}{l|c|c|c|c|c|c}
\hline \multirow{2}{*}{ Treatments } & \multicolumn{2}{|c|}{ Pods plant $^{-1}$ (no.) } & \multicolumn{2}{c|}{ Seeds pod $^{-1}$ (no.) } & \multicolumn{2}{c}{1000 -seed weight (g) } \\
\cline { 2 - 7 } & 2012 & 2013 & 2012 & 2013 & 2012 & 2013 \\
\hline $\mathrm{T}_{1}:$ Control & $11.1 \mathrm{~d}$ & $10.9 \mathrm{c}$ & $9.0 \mathrm{~b}$ & $9.2 \mathrm{~d}$ & $35.9 \mathrm{~b}$ & 39.7 \\
$\mathrm{~T}_{2}: 100 \% \mathrm{CF}$ & $18.4 \mathrm{c}$ & $15.5 \mathrm{~b}$ & $10.3 \mathrm{a}$ & $11.4 \mathrm{c}$ & $37.9 \mathrm{ab}$ & 39.7 \\
$\mathrm{~T}_{3}: \mathrm{CD}+\mathrm{CF}$ & $18.2 \mathrm{c}$ & $15.9 \mathrm{ab}$ & $10.7 \mathrm{a}$ & $11.6 \mathrm{bc}$ & $38.1 \mathrm{ab}$ & 39.9 \\
$\mathrm{~T}_{4}: \mathrm{CD}$ slurry + CF & $20.1 \mathrm{~b}$ & $16.4 \mathrm{ab}$ & $10.8 \mathrm{a}$ & $11.8 \mathrm{ab}$ & $38.2 \mathrm{ab}$ & 39.8 \\
$\mathrm{~T}_{5}: \mathrm{PM}+\mathrm{CF}$ & $20.5 \mathrm{ab}$ & $16.3 \mathrm{ab}$ & $10.6 \mathrm{a}$ & $11.6 \mathrm{bc}$ & $38.2 \mathrm{ab}$ & 39.7 \\
$\mathrm{~T}_{6}: \mathrm{PM}$ slurry + CF & $20.8 \mathrm{ab}$ & $15.6 \mathrm{~b}$ & $10.9 \mathrm{a}$ & $11.8 \mathrm{ab}$ & $39.9 \mathrm{a}$ & 39.7 \\
$\mathrm{~T}_{7}: \mathrm{TC}+\mathrm{CF}$ & $21.3 \mathrm{a}$ & $17.5 \mathrm{a}$ & $11.1 \mathrm{a}$ & $12.2 \mathrm{a}$ & $40.1 \mathrm{a}$ & 39.7 \\
$\mathrm{~T}_{8}: \mathrm{VC}+\mathrm{CF}$ & $21.3 \mathrm{a}$ & $16.1 \mathrm{ab}$ & $10.7 \mathrm{a}$ & $11.6 \mathrm{bc}$ & $39.9 \mathrm{a}$ & 40.1 \\
$\mathrm{CV}(\%)$ & 3.30 & 9.01 & 5.76 & 2.75 & 3.28 & 1.10 \\
Level of significance & $* *$ & $* *$ & $*$ & $* *$ & $*$ & NS \\
$\mathrm{SE}( \pm)$ & 0.361 & 0.5709 & 0.350 & 0.1277 & 0.730 & 0.178 \\
\hline
\end{tabular}

Means followed by same letter in a column are not significantly different at $5 \%$ level by DMRT. SE $( \pm)$ $=$ Standard error of means, CV $=$ Coefficient of variation, $* *=$ Significant at $1 \%$ level, $*=$ Significant at $5 \%$ level NS $=$ Not significant, $\mathrm{HYG}=$ High Yield Goal, $\mathrm{CF}=$ Chemical Fertilizer, IPNS $=$ Integrated Plant Nutrition System, CD = Cowdung, CD slurry = Cowdung slurry, PM = Poultry manure, PM slurry $=$ Poultry manure slurry, $\mathrm{TC}=$ Trichocompost, $\mathrm{VC}=$ Vermicompost

Like other parameters, the 1000-seed weight of mung bean was significantly influenced by the different treatments especially in the first year showing a range of $35.9-40.1 \mathrm{~g}$ (Table 1). The $\mathrm{T}_{7}$ treatment $(\mathrm{TC}+\mathrm{CF})$ showed the highest 1000 -seed weight (40.1g) which however was statistically similar with all other treatments except control. Unlike first year result, the 1000-seed weight remained statistically similar for all the treatments indicating no residual effect of IPNS or lone fertilizer treatments. In value, the 1000-seed weight varied from 39.7-40.1 g due to different treatments. The findings are in corroboration with Reddy and Reddy (2005) who reported that growth and yield attributes of radish were significantly affected due to the residual effect of vermicompost in onion-radish cropping system.

\section{Seed and stover yields}

Application of different manures with chemical fertilizers had significant residual effect on the seed yield as well as stover yield of mungbean (Table 2). Depending on 
the treatments, the seed yield ranged from 0.54 to $1.54 \mathrm{t} \mathrm{ha}^{-1}$ in 2012 and $0.67-1.69 \mathrm{t}$ $\mathrm{ha}^{-1}$ in 2013. In both the years, the highest seed yield was obtained from $\mathrm{T}_{7}$ treatment $(\mathrm{TC}+\mathrm{CF})$ and the highest yield was superior to all other treatments in 2012 and identical with $\mathrm{T}_{6}$ and $\mathrm{T}_{8}$ treatments in 2013. The lowest seed yield was recorded with control treatment in both years. In the year 2012, treatments $\mathrm{T}_{4}(\mathrm{CD}$ slurry $+\mathrm{CF}), \mathrm{T}_{6}$ $(\mathrm{PM}$ slurry $+\mathrm{CF})$ and $\mathrm{T}_{8}(\mathrm{VC}+\mathrm{CF})$ were statistically similar followed by $\mathrm{T}_{5}$ treatment (poultry manure $+\mathrm{CF}$ ). In 2013 , generally next to $\mathrm{T}_{7}$, all other IPNS treatments $\left(\mathrm{T}_{3}-\mathrm{T}_{6} \& \mathrm{~T}_{8}\right)$ had similar effect and they all were superior to exclusive fertilizer treatment $\left(\mathrm{T}_{2}\right)$. On the other hand, the stover yield ranged from $1.41-3.64 \mathrm{t}$ $\mathrm{ha}^{-1}$ in the first year and 1.76-3.86 t ha-1 in the second year (Table 2). In year-1, treatments $\mathrm{T}_{5}-\mathrm{T}_{8}$ had similar effect and in year- $2, \mathrm{~T}_{3}-\mathrm{T}_{8}$ had similar effect on the stover yield. These results are in fully similar with the findings of Suthamathy and Seran (2013) who found that application of EM (effective microorganisms) bokashi can provide significant amount of residual nutrients for cultivation of a short durational succeeding crop and the residual benefits depend on the initial nutrient of manure.

Such result indicates that IPNS treatments had mostly similar effect showing that all manures viz. cowdung, poultry manure, trichocompost and vermicompost reasonably had an equal manure value. Every IPNS treatment was generally better than $100 \%$ fertilizer treatment $\left(\mathrm{T}_{2}\right)$. The lowest stover yield was noted in the control $\left(\mathrm{T}_{1}\right)$. It appeared that yield performance of compost (vermicompost and trichocompost) was better than that of cowdung and poultry manure. Again, slurry effect was found better than original cowdung or poultry manure effect. Compared to $100 \%$ fertilizer, the addition of manure and fertilizer resulted in a 7-28\% increase in seed yield, as observed in the first year. The results with those of Umunna and Anselem (2014), Singh et al. (2014) and Suryantini (2016). Apart from enhancing crop yield, the practice of IPNS has a greater beneficial residual effect than the sole use of mineral fertilizer or organic materials (Demelash et al., 2014). For example, integrated use of inorganic fertilizers and vermicompost in broccoli crop significantly influenced the succeeding cowpea growth, yield and soil fertility (Ranjit, 2014). Vermicompost and trichocompost are good sources of nutrient elements namely N, P, K and S and they contain a large beneficial microbial population and biologically active metabolites which on application alone or in combination with organic or inorganic fertilizers, can give better yield and quality of crops (Rahman 2009; Arancon and Edwards, 2011). 
Table 2. Integrated effects of manure and fertilizers on seed and stover yields of mungbean (Binamung-8) in the potato- mungbean - T. aman rice cropping pattern

\begin{tabular}{l|cc|cc}
\hline \multirow{2}{*}{ Treatments } & \multicolumn{2}{|c|}{ Seed yield $\left(\mathrm{t} \mathrm{ha}^{-1}\right)$} & \multicolumn{2}{c}{ Stover yield $\left(\mathrm{t} \mathrm{ha}^{-1}\right)$} \\
\cline { 2 - 5 } & 2012 & 2013 & 2012 & 2013 \\
\hline $\mathrm{T}_{1}:$ Control & $0.54 \mathrm{f}$ & $0.67 \mathrm{~d}$ & $1.41 \mathrm{c}$ & $1.76 \mathrm{c}$ \\
$\mathrm{T}_{2}: 100 \% \mathrm{CF}$ & $1.05 \mathrm{e}$ & $1.38 \mathrm{c}$ & $2.87 \mathrm{~b}$ & $3.61 \mathrm{~b}$ \\
$\mathrm{~T}_{3}: \mathrm{CD}+\mathrm{CF}$ & $1.16 \mathrm{~d}$ & $1.46 \mathrm{bc}$ & $2.77 \mathrm{~b}$ & $3.67 \mathrm{ab}$ \\
$\mathrm{T}_{4}: \mathrm{CD}$ slurry + CF & $1.26 \mathrm{bc}$ & $1.52 \mathrm{~b}$ & $2.91 \mathrm{~b}$ & $3.74 \mathrm{ab}$ \\
$\mathrm{T}_{5}: \mathrm{PM}+\mathrm{CF}$ & $1.21 \mathrm{~cd}$ & $1.55 \mathrm{~b}$ & $3.32 \mathrm{a}$ & $3.66 \mathrm{ab}$ \\
$\mathrm{T}_{6}: \mathrm{PM}$ slurry $+\mathrm{CF}$ & $1.27 \mathrm{bc}$ & $1.59 \mathrm{ab}$ & $3.52 \mathrm{a}$ & $3.80 \mathrm{ab}$ \\
$\mathrm{T}_{7}: \mathrm{TC}+\mathrm{CF}$ & $1.54 \mathrm{a}$ & $1.69 \mathrm{a}$ & $3.49 \mathrm{a}$ & $3.86 \mathrm{a}$ \\
$\mathrm{T}_{8}: \mathrm{VC}+\mathrm{CF}$ & $1.34 \mathrm{~b}$ & $1.56 \mathrm{ab}$ & $3.64 \mathrm{a}$ & $3.78 \mathrm{ab}$ \\
$\mathrm{CV}(\%)$ & 4.03 & 7.24 & 6.05 & 4.91 \\
Level of significance & $* *$ & $* *$ & $* *$ & $* *$ \\
SE $( \pm)$ & 0.0272 & 0.0421 & 0.1044 & 0.0699 \\
\hline
\end{tabular}

Means followed by same letter in a column are not significantly different at $5 \%$ level by DMRT .SE $( \pm)$ $=$ Standard error of means, $\mathrm{CV}=$ Coefficient of variation, $* *=$ Significant at $1 \%$ level, $\mathrm{HYG}=$ High Yield Goal, $\mathrm{CF}=$ Chemical Fertilizer, IPNS = Integrated Plant Nutrition System, CD = Cowdung, CD slurry $=$ Cowdung slurry, $\mathrm{PM}=$ Poultry manure, $\mathrm{PM}$ slurry $=$ Poultry manure slurry, $\mathrm{TC}$ $=$ Trichocompost, $\mathrm{VC}=$ Vermicompost

\section{Nutrient concentration}

In both the year, the treatments with organic manures significantly increased the contents of nutrients viz. N, K, P and S (except seed S) in mung bean seed and stover compared to control (Table 3 and Table 4). Among all the organic manures, trichocompost showed the highest $\mathrm{N}$ concents in seed and stover for both years. For seed $\mathrm{N}$ contents, all the treatments were statistically identical except control in 2012 while $\mathrm{T}_{3}, \mathrm{~T}_{4}, \mathrm{~T}_{7}$ and $\mathrm{T}_{8}$ had no difference in 2013. In 2012, $\mathrm{TC}+\mathrm{CF}$ produced the highest $\mathrm{K}$ concentration in seed which was not statistically similar with other treatments in 2012 wheareas in 2013, PM + CF produced the highest seed $\mathrm{K}$ which was at per with other treatments except control. The highest stover K in 2012 and 2013 in were observed in $\mathrm{CD}+\mathrm{CF}$ and $\mathrm{TC}+\mathrm{CF}$, respectively. The minimum $\mathrm{N}$ and $\mathrm{K}$ contents in both seed and stover in both years were noted in control. 
Table 3. Effects of different types of manure integrated with fertilizers on the $\mathrm{N}$ content $(\%)$ and $\mathrm{K}$ content $(\%)$ of mungbean (seed and stover) in the potatomungbean- $\mathrm{T}$. aman rice cropping pattern

\begin{tabular}{|c|c|c|c|c|c|c|c|c|}
\hline \multirow{3}{*}{ Treatments } & \multicolumn{4}{|c|}{$\% \mathrm{~N}$ content } & \multicolumn{4}{|c|}{$\% \mathrm{~K}$ content } \\
\hline & \multicolumn{2}{|c|}{ Seed } & \multicolumn{2}{|c|}{ Stover } & \multicolumn{2}{|c|}{ Seed } & \multicolumn{2}{|c|}{ Stover } \\
\hline & 2012 & 2013 & 2012 & 2013 & 2012 & 2013 & 2012 & 2013 \\
\hline $\mathrm{T}_{1}$ : Control & $3.36 \mathrm{~b}$ & $3.45 \mathrm{c}$ & $1.22 \mathrm{c}$ & $0.099 \mathrm{~d}$ & $1.206 \mathrm{~d}$ & $1.414 \mathrm{~b}$ & $1.317 \mathrm{c}$ & $1.681 \mathrm{c}$ \\
\hline $\mathrm{T}_{2}: 100 \% \mathrm{CF}$ & $3.59 \mathrm{a}$ & $3.54 \mathrm{bc}$ & $1.31 \mathrm{~b}$ & $1.32 \mathrm{c}$ & $1.219 \mathrm{~d}$ & $1.609 \mathrm{a}$ & $1.505 \mathrm{ab}$ & $1.931 \mathrm{ab}$ \\
\hline $\mathrm{T}_{3}: \mathrm{CD}+\mathrm{CF}$ & $3.56 \mathrm{a}$ & $3.68 \mathrm{ab}$ & $1.27 \mathrm{bc}$ & $1.31 \mathrm{c}$ & $1.269 \mathrm{~cd}$ & $1.636 \mathrm{a}$ & $1.550 \mathrm{a}$ & $1.891 \mathrm{~b}$ \\
\hline $\mathrm{T}_{4}: \mathrm{CD}$ slurry $+\mathrm{CF}$ & $3.60 \mathrm{a}$ & $3.66 \mathrm{ab}$ & $1.32 \mathrm{~b}$ & $1.52 \mathrm{ab}$ & $1.295 \mathrm{c}$ & $1.621 \mathrm{a}$ & $1.536 \mathrm{a}$ & $1.872 b$ \\
\hline $\mathrm{T}_{5}: \mathrm{PM}+\mathrm{CF}$ & $3.58 \mathrm{a}$ & $3.56 \mathrm{bc}$ & $1.27 b c$ & $1.52 \mathrm{ab}$ & $1.323 b c$ & $1.650 \mathrm{a}$ & $1.519 \mathrm{ab}$ & $1.917 \mathrm{ab}$ \\
\hline $\mathrm{T}_{6}: \mathrm{PM}$ slurry $+\mathrm{CF}$ & $3.64 \mathrm{a}$ & $3.62 b$ & $1.46 \mathrm{a}$ & $1.45 b$ & $1.290 \mathrm{c}$ & $1.601 \mathrm{a}$ & $1.537 \mathrm{a}$ & $1.884 b$ \\
\hline $\mathrm{T}_{7}: \mathrm{TC}+\mathrm{CF}$ & $3.66 \mathrm{a}$ & $3.77 \mathrm{a}$ & $1.49 \mathrm{a}$ & $1.55 \mathrm{a}$ & $1.452 \mathrm{a}$ & $1.647 \mathrm{a}$ & $1.541 \mathrm{a}$ & $1.991 \mathrm{a}$ \\
\hline $\mathrm{T}_{8}: \mathrm{VC}+\mathrm{CF}$ & $3.52 \mathrm{a}$ & $3.63 \mathrm{ab}$ & $1.27 \mathrm{~b}$ & $1.46 \mathrm{ab}$ & $1.373 b$ & $1.611 \mathrm{a}$ & $1.475 b$ & $1.946 \mathrm{ab}$ \\
\hline $\mathrm{CV}(\%)$ & 2.36 & 3.31 & 2.71 & 5.01 & 2.85 & 3.34 & 2.03 & 3.80 \\
\hline Level of significance & $*$ & $* *$ & $* *$ & $* *$ & $* *$ & $* *$ & $* *$ & $* *$ \\
\hline $\mathrm{SE}( \pm)$ & 0.0486 & 0.0488 & 0.0207 & 0.0284 & 0.0214 & 0.0218 & 0.0176 & 0.029 \\
\hline
\end{tabular}

Means followed by the same letter in a column are not significantly different at $5 \%$ level by DMRT

SE $( \pm)=$ Standard error of means, CV= Coefficient of variation, $* *=$ Significant at $1 \%$ level, $*=$ Significant at 5\% level, , HYG = High Yield Goal, CF $=$ Chemical Fertilizer, IPNS = Integrated Plant Nutrition System, CD = Cowdung, CD slurry = Cowdung slurry, PM = Poultry manure, PM slurry = Poultry manure slurry, $\mathrm{TC}=$ Trichocompost, $\mathrm{VC}=$ Vermicompost

In 2012, the maximum $\mathrm{P}$ content in seed and stover were observed in $\mathrm{T}_{6}$ while in 2013, the maximum $P$ content in seed and stover were observed in $T_{7}$. In general, for $\mathrm{P}$ content in seed and stover in both years, there was no significant difference among the treatments $\mathrm{T}_{5}, \mathrm{~T}_{6}, \mathrm{~T}_{7}$, and $\mathrm{T}_{8}$. In case of mungbean seed $\mathrm{S}$ concentration, all the treatments were statistically similar. Interestingly, $\mathrm{T}_{8}$ and $\mathrm{T}_{7}$ produced the highest stover S content in 2012 and 2013, respectively and they were statistically identical. The results of the present study are in agreement with those of Sarwar et al. (2009) and Namazi et al. (2015). 
Table 4. Effects of different types of manure integrated with fertilizers on the $\mathrm{P}$ content $(\%)$ and $\mathrm{S}$ content $(\%)$ of mungbean (seed \& stover) in the potatomungbean- $\mathrm{T}$. aman rice cropping pattern

\begin{tabular}{l|c|c|c|c|c|c|c|c}
\hline \multirow{2}{*}{ Treatments } & \multicolumn{4}{c|}{ Phosphorus } & \multicolumn{4}{c}{ Sulphur } \\
\cline { 2 - 10 } & \multicolumn{2}{c}{ Seed } & \multicolumn{2}{c|}{ Stover } & \multicolumn{2}{c}{ Seed } & \multicolumn{3}{c}{ Stover } \\
\cline { 2 - 10 } & 2012 & 2013 & 2012 & 2013 & 2012 & 2013 & 2012 & 2013 \\
\hline $\mathrm{T}_{1}:$ Control & $0.303 \mathrm{~d}$ & $0.368 \mathrm{c}$ & $0.130 \mathrm{e}$ & $0.090 \mathrm{~d}$ & 0.121 & 0.137 & $0.136 \mathrm{~d}$ & $0.135 \mathrm{~d}$ \\
$\mathrm{~T}_{2}: 100 \% \mathrm{CF}$ & $0.395 \mathrm{abc}$ & $0.454 \mathrm{~b}$ & $0.175 \mathrm{bc}$ & $0.141 \mathrm{c}$ & 0.136 & 0.151 & $0.155 \mathrm{bc}$ & $0.153 \mathrm{c}$ \\
$\mathrm{T}_{3}: \mathrm{CD}+\mathrm{CF}$ & $0.363 \mathrm{c}$ & $0.476 \mathrm{ab}$ & $0.134 \mathrm{de}$ & $0.146 \mathrm{c}$ & 0.135 & 0.147 & $0.166 \mathrm{ab}$ & $0.152 \mathrm{c}$ \\
$\mathrm{T}_{4}: \mathrm{CD}$ slurry + CF & $0.377 \mathrm{bc}$ & $0.475 \mathrm{ab}$ & $0.163 \mathrm{~cd}$ & $0.172 \mathrm{~b}$ & 0.142 & 0.154 & $0.156 \mathrm{bc}$ & $0.158 \mathrm{c}$ \\
$\mathrm{T}_{5}: \mathrm{PM}+\mathrm{CF}$ & $0.418 \mathrm{ab}$ & $0.483 \mathrm{a}$ & $0.178 \mathrm{bc}$ & $0.208 \mathrm{a}$ & 0.134 & 0.137 & $0.145 \mathrm{~cd}$ & $0.173 \mathrm{~b}$ \\
$\mathrm{~T}_{6}: \mathrm{PM}$ slurry + CF & $0.426 \mathrm{a}$ & $0.490 \mathrm{a}$ & $0.225 \mathrm{a}$ & $0.219 \mathrm{a}$ & 0.143 & 0.151 & $0.168 \mathrm{ab}$ & $0.175 \mathrm{~b}$ \\
$\mathrm{~T}_{7}: \mathrm{TC}+\mathrm{CF}$ & $0.416 \mathrm{ab}$ & $0.492 \mathrm{a}$ & $0.204 \mathrm{ab}$ & $0.222 \mathrm{a}$ & 0.139 & 0.146 & $0.181 \mathrm{a}$ & $0.187 \mathrm{a}$ \\
$\mathrm{T}_{8}: \mathrm{VC}+\mathrm{CF}$ & $0.413 \mathrm{ab}$ & $0.482 \mathrm{a}$ & $0.207 \mathrm{ab}$ & $0.188 \mathrm{~b}$ & 0.135 & 0.144 & $0.183 \mathrm{a}$ & $0.178 \mathrm{ab}$ \\
$\mathrm{CV}(\%)$ & 6.26 & 4.63 & 9.95 & 8.67 & 8.70 & 9.41 & 6.26 & 5.18 \\
Level of significance & $* *$ & $* *$ & $* *$ & $* *$ & $\mathrm{NS}$ & $\mathrm{NS}$ & $* *$ & $* *$ \\
$\mathrm{SE}( \pm)$ & 0.0141 & 0.0088 & 0.0102 & 0.0061 & 0.6812 & 0.0079 & 0.0058 & 0.0069 \\
\hline
\end{tabular}

Means followed by the same letter in a column are not significantly different at $5 \%$ level by DMRT

SE $( \pm)=$ Standard error of means, CV $=$ Coefficient of variation, $* *=$ Significant at $1 \%$ level, $\mathrm{NS}=$ Not significant, $\mathrm{HYG}=$ High Yield Goal, $\mathrm{CF}=$ Chemical Fertilizer, IPNS $=$ Integrated Plant Nutrition System,$C D=$ Cowdung, $C D$ slurry $=$ Cowdung slurry, $\mathrm{PM}=$ Poultry manure, PM slurry $=$ Poultry manure slurry, $\mathrm{TC}=$ Trichocompost, $\mathrm{VC}=$ Vermicompost

\section{Nutrient uptake}

The treatments had significant residual effect on the uptake of $\mathrm{N}, \mathrm{P}, \mathrm{K}$ and $\mathrm{S}$ by mung bean. The total $\mathrm{N}$ uptake (seed $\mathrm{N}$ uptake + stover $\mathrm{N}$ uptake) by mung bean in 2012 varied from 35.42 to $108.4 \mathrm{~kg} \mathrm{ha}^{-1}$ in 2012 and ranged from $40.5-123.6 \mathrm{~kg} \mathrm{ha}^{-1}$ in 2013 (Table 5). In both years, $\mathrm{T}_{7}$ treatment (trichocompost + chemical fertilizers) clearly showed its superiority over all other treatments. Next to $T_{7}$, the $T_{8}$ (vermicompost + fertilizers) and $\mathrm{T}_{6}$ (poultry manure + fertilizers) treatments resulted in higher $\mathrm{N}$ uptake, with a record of 94.6 and $111.8 \mathrm{~kg} \mathrm{ha}^{-1}$ for $\mathrm{T}_{8}$ and 98.13 and $112.4 \mathrm{~kg} \mathrm{ha}^{-1}$ for $\mathrm{T}_{6}$ treatments in two years, respectively. Residual effect of slurry was found better than that of original manure. Again, the effect of $100 \%$ fertilizer and IPNS with cowdung was similar.

The $\mathrm{K}$ uptake showed a range of $25.08-73.75 \mathrm{~kg} \mathrm{ha}^{-1}$ in 2012 and $39.09-104.6 \mathrm{~kg}$ $\mathrm{ha}^{-1}$ in 2013 (Table 5), with the highest $\mathrm{K}$ uptake recorded by $\mathrm{T}_{7}$ and the lowest $\mathrm{K}$ 
uptake noted with $\mathrm{T}_{1}$ (control). After $\mathrm{T}_{7}$, treatments $\mathrm{T}_{8}$ and $\mathrm{T}_{6}$ had higher $\mathrm{K}$ uptake, the values being 72.98 and $70.93 \mathrm{~kg} \mathrm{ha}^{-1}$, respectively for the first year and the corresponding values being 98.68 and $96.87 \mathrm{~kg} \mathrm{ha}^{-1}$ for the second year. Treatments $\mathrm{T}_{2}$ (exclusively fertilizer treatment) and $\mathrm{T}_{3}$ (cowdung + fertilizer on IPNS basis) exhibited similar K uptake.

Table 5. Integrated effects of manure and fertilizers on $\mathrm{N}, \mathrm{K}, \mathrm{P}$ and $\mathrm{S}$ uptake by mungbean (seed + stover) in the potato- mungbean $-\mathrm{T}$. aman rice cropping pattern

\begin{tabular}{l|c|c|c|c|c|c|c|c}
\hline \multirow{2}{*}{ Treatments } & \multicolumn{2}{|c|}{$\mathrm{N}$ uptake $\left(\mathrm{kg} \mathrm{ha}^{-1}\right)$} & \multicolumn{2}{c|}{$\mathrm{K}$ uptake $\left(\mathrm{kg} \mathrm{ha}^{-1}\right)$} & \multicolumn{2}{c}{$\mathrm{P}$ uptake $\left(\mathrm{kg} \mathrm{ha}^{-1}\right)$} & \multicolumn{3}{c}{$\mathrm{S}$ uptake $\left(\mathrm{kg} \mathrm{ha}^{-1}\right)$} \\
\cline { 2 - 10 } & 2012 & 2013 & 2012 & 2013 & 2012 & 2013 & 2012 & 2013 \\
\hline $\mathrm{T}_{1}:$ Control & $35.42 \mathrm{e}$ & $40.50 \mathrm{~d}$ & $25.08 \mathrm{e}$ & $39.09 \mathrm{~d}$ & $3.47 \mathrm{e}$ & $4.02 \mathrm{f}$ & $2.58 \mathrm{c}$ & $3.30 \mathrm{e}$ \\
$\mathrm{T}_{2}: 100 \% \mathrm{CF}$ & $75.14 \mathrm{~d}$ & $96.21 \mathrm{c}$ & $55.89 \mathrm{~d}$ & $91.81 \mathrm{c}$ & $9.16 \mathrm{c}$ & $11.32 \mathrm{e}$ & $5.86 \mathrm{~b}$ & $7.59 \mathrm{~d}$ \\
$\mathrm{~T}_{3}: \mathrm{CD}+\mathrm{CF}$ & $74.92 \mathrm{~d}$ & $101 \mathrm{i} .9 \mathrm{c}$ & $57.02 \mathrm{~d}$ & $93.30 \mathrm{c}$ & $7.893 \mathrm{~d}$ & $12.30 \mathrm{e}$ & $6.15 \mathrm{~b}$ & $7.71 \mathrm{~d}$ \\
$\mathrm{~T}_{4}: \mathrm{CD}$ slurry + CF & $83.70 \mathrm{c}$ & $112.3 \mathrm{~b}$ & $60.76 \mathrm{~cd}$ & $94.62 \mathrm{bc}$ & $9.497 \mathrm{c}$ & $13.64 \mathrm{~d}$ & $6.35 \mathrm{~b}$ & $8.22 \mathrm{~d}$ \\
$\mathrm{~T}_{5}: \mathrm{PM}+\mathrm{CF}$ & $86.09 \mathrm{c}$ & $110.71 \mathrm{~b}$ & $66.15 \mathrm{bc}$ & $95.63 \mathrm{bc}$ & $11.01 \mathrm{~b}$ & $15.11 \mathrm{bc}$ & $6.44 \mathrm{~b}$ & $8.45 \mathrm{bc}$ \\
$\mathrm{T}_{6}: \mathrm{PM}$ slurry + CF & $98.13 \mathrm{~b}$ & $112.4 \mathrm{~b}$ & $70.93 \mathrm{ab}$ & $96.87 \mathrm{bc}$ & $13.35 \mathrm{a}$ & $16.07 \mathrm{ab}$ & $7.72 \mathrm{a}$ & $9.07 \mathrm{~b}$ \\
$\mathrm{~T}_{7}: \mathrm{TC}+\mathrm{CF}$ & $108.4 \mathrm{a}$ & $123.6 \mathrm{a}$ & $73.75 \mathrm{a}$ & $104.6 \mathrm{a}$ & $13.53 \mathrm{a}$ & $16.89 \mathrm{a}$ & $8.46 \mathrm{a}$ & $9.68 \mathrm{a}$ \\
$\mathrm{T}_{8}: \mathrm{VC}+\mathrm{CF}$ & $94.60 \mathrm{~b}$ & $111.8 \mathrm{~b}$ & $72.98 \mathrm{a}$ & $98.68 \mathrm{~b}$ & $12.99 \mathrm{a}$ & $14.63 \mathrm{~cd}$ & $8.45 \mathrm{a}$ & $8.99 \mathrm{ab}$ \\
$\mathrm{CV}(\%)$ & 4.45 & 4.92 & 5.18 & 4.36 & 6.99 & 6.74 & 8.41 & 7.04 \\
Level of significance & $* *$ & $* *$ & $* *$ & $* *$ & $* *$ & $* *$ & $* *$ & $* *$ \\
$\mathrm{SE}( \pm)$ & 2.109 & 2.034 & 1.805 & 1.591 & 0.408 & 0.357 & 0.316 & 0.393 \\
\hline
\end{tabular}

Means followed by same letter in a column are not significantly different at $5 \%$ level by DMRT.

$\mathrm{SE}( \pm)=$ Standard error of means, CV = Coefficient of variation, $* *=$ Significant at $1 \%$ level, $\mathrm{HYG}=$ High Yield Goal, CF = Chemical Fertilizer, IPNS = Integrated Plant Nutrition System, CD = Cowdung, $\mathrm{CD}$ slurry $=$ Cowdung slurry, $\mathrm{PM}=$ Poultry manure, $\mathrm{PM}$ slurry $=$ Poultry manure slurry, $\mathrm{TC}$ $=$ Trichocompost, $\mathrm{VC}=$ Vermicompost

The $\mathrm{P}$ uptake by mung bean was markedly influenced by the residual effect of organic manure and fertilizer treatments (Table 5). Total P uptake (seed + stover) by mung bean varied from 3.47 to $13.53 \mathrm{~kg} \mathrm{ha}^{-1}$ in 2012 and from 4.02 to $16.89 \mathrm{~kg} \mathrm{ha}^{-1}$ in 2013. Like $\mathrm{N}$ and $\mathrm{K}$ uptake, $\mathrm{T}_{7}$ recorded the highest $\mathrm{P}$ uptake and the control treatment $\left(\mathrm{T}_{1}\right)$ did the lowest. Next to trichocompost containing treatment, poultry manure slurry comprising fertilizer treatment demonstrated the highest $\mathrm{P}$ uptake. Overall result indicates that the residual effect of IPNS treatments was better than that of lone fertilizer $\left(\mathrm{T}_{2}\right)$ treatment. Like $\mathrm{N}, \mathrm{K}$ and $\mathrm{P}$ uptake, the $\mathrm{S}$ uptake by mung bean markedly varied due to residual effects of the IPNS treatments (Table 5). The maximum $\mathrm{S}$ uptake was due to use of $\mathrm{T}_{7}$ (trichocompost plus chemical fertilizers) 
treatment and the minimum $\mathrm{S}$ uptake due to $\mathrm{T}_{1}$ (no manure or fertilizer) treatment. Treatment $T_{7}$ did not differ significantly from $T_{6}$ and $T_{8}$ for the first year and from $T_{8}$ only for the second year. The treatments with $100 \%$ fertilizer and IPNS basis cowdung and cowdung slurry containing treatments had alike $\mathrm{S}$ uptake by the crop. It was further observed that slurry effect was better than that of original manure used for the first crop (potato). Rafique et al., 2012 and Kumar et al 2015 also found increased nutrient uptake in mung bean by combined use of organic and inorganic fertilizers.

\section{CONCLUSIONS}

The present study suggests that the use of IPNS on potato-mung bean-rice cropping pattern had significant positive residual effects on yield parameters of mung bean such as number of pods plant ${ }^{-1}$, and number of seeds pod ${ }^{-1}$ and improved seed and stover yield of mung bean. This study also suggests that application of IPNS can increase $\mathrm{N}, \mathrm{P}, \mathrm{K}$ and $\mathrm{S}$ content as well as uptake by mung bean. Therefore, application of vermicompost or Trichocompost in combination with inorganic fertilizers can be recommended for better yield and nutritional quality in mung bean.

\section{ACKNOWLEDGEMENTS}

We gratefully acknowledge the financial support provided by the HEQEP project to carry out this research work.

\section{REFERENCES}

Ali, R.I., Awan, T.H., Ahmad, M., Saleem, M.U., and Akhtar, M. (2012). Diversification of rice-based cropping systems to improve soil fertility, sustainable productivity and economics. The Journal of Animal \& Plant Sciences, 22(1), 108-111.

Arancon, N.Q., and Edwards, C.A. (2011). The use of vermicomposts as soil amendments for production of field crops. p. 129-151. In C.A. Edwards N.Q. Arancon \& R. Sherman (eds), Vermiculture Technology: Earthworms, Organic Wastes, and Environmental Management. Boca Raton, London, New York: CRC Press, Taylor \& Francis Group.

Bourgault, M., Madramootoo, C.A., Webber, H.A., Stulina, G., Horst, M.G., and Smith, D.L. (2010). Effects of deficit irrigation and salinity stress on common bean (Phaseolus vulgaris L.) and mungbean (Vigna radiata L.) Wilczek grown in a controlled environment. Journal of Agronomy and Crop Science, 196, 262-272.

Brady, N.C., and Weil, R.C. (2012). The Nature and Properties of Soils. $14^{\text {th }}$ Edn (Revised). Published by Dorling Kin Dersley (India) Pvt. Ltd., licensees of Pearson Education in Asia, India, pp. 513-517.

Davari, M., Sharma, S.N., and Mirzakhani, M. (2012). Residual influence of organic materials, crop residues, and biofertilizers on performance of succeeding mung bean in an organic rice-based cropping system. International Journal of Recycling of Organic Waste in Agriculture, 1, 14. doi:10.1186/2251-7715-1-14. 
Demelash, N., Bayu, W., Tesfaye, S., Ziadat, F., and Sommer, R. (2014). Current and residual effects of compost and inorganic fertilizer on wheat and soil chemical properties. Nutrient Cycling in Agroecosystem 100(3), 357-367.

FRG (Fertilizer Recommendation Guide). (2012). Bangladesh Agricultural Research Council (BARC), Dhaka, Bangladesh.

Gomez, K.A., and Gomez, A.A. (1984). Statistical Procedures for Agricultural Research, John Wiley and Sons, New York. pp. 202-215.

Heitkamp, F., Raupp, J., and Ludwig, B. (2011). Soil organic matter pools and crop yields as affected by the rate of farmyard manure and use of biodynamic preparations in a sandy soil. Organic Agriculture 1, 111-124.

Jeptoo, A., Aguyoh, J.N., and Saidi, M. (2013). Improving carrot yield and quality through the use of bio-slurry manure. Sustainable Agriculture Research 2(1),164-172.

Kumar, R., Deka, B.C., and Ngachan, S.V. (2015). Response of summer mungbean to sowing time, seed rates and integrated nutrient management. Legume Research, 38(3), 348352.

Meena, S., Swaroop, N., and Dawson, J. (2016). Effect of integrated nutrient management on growth and yield of green gram (Vigna radiata L.). Agricultural Science Digest, 36(1), 63-65.

Namazi, E., Lack, S., and Nejad, E.F. (2015). Effect of vermicompost and chemical nitrogen fertilizer application on the various functioning of maize seeds. Journal of Experimental Biology and Agricultural Sciences 3(3), 261-268.

Prajapati, S.K., Tyagi, P.K., Chourasia, S.K., and Upadhyay, A.K. (2016). Effect of integrated nutrient management practices on growth and yield of summer mungbean (Vigna Radiata L.). TECHNOFAME-A Journal of Multidisciplinary Advance Research, 5(1), 102-107.

Prasad, R. (2005). Rice-wheat cropping system. Advances in Agronomy, 86:285-339.

Rafique, E., Mahmood-ul-Hassan, M., Rashid, A., and Chaudhary, M.F. (2012). Nutrient balances as affected by integrated nutrient and crop residue management in cottonwheat system in Aridisols. I. Nitrogen. Journal of Plant Nutrition 35, 591-616.

Rahman, A. (2009). Screening of Trichoderma spp. and their efficacy as a bio-conversion agent of municipal solid waste through appropriate technique of solid state fermentation.PhD Thesis, Department of Botany, University of Rajshahi, Rajshahi6205, Bangladesh.

Rahman, J., Riad, M.I., Islam, M., Akter, A., and Islam, M.F. (2018). Rice-based cropping pattern for increasing cropping intensity and productivity in Jamalpur region under AEZ 09. International Journal of Natural and Social Sciences, 5(2), 35-41.

Ranjit, C. (2014). Residual effect of vermicompost and inorganic fertilizers of sprouting broccoli on succeeding cowpea growth, yield and soil fertility for eastern Himalayan region. $2^{\text {nd }}$ International Conference on Agricultural \& Horticultural Science. Feb 0305 , Hyderabad, India.

Reddy, K.C., and Reddy, K.M. (2005). Differential levels of vermicompost and nitrogen on growth and yield of onion (Allium cepa L.) Radish (Raphanus sativus L.) cropping system. The Journal of Research ANGRAU, 33(1), 11-17. 
Sarwar, G., Hussain, N., Schmeisky, H., Suhammad, S., Ibrahim, M., and Ahmad, S. (2009). Efficiency of various organic residues for enhancing rice-wheat production under normal soil conditions. Pakistan Journal of Botany 40, 2107-2113.

Singh, A.K., Singh, A.K., Kumar, M., Bordoloi, L.J., and Jha, A.K. (2014). Nutrient management for improving mungbean (Vigna radiata) productivity in acidic soil of northeast India. Indian Journal of Hill Farming 27(1), 62-71.

Singh, B.K., Pathak, K.A., Boopathi, T., and Deka, B.C. (2010). Vermicompost and NPK fertilizer effects on morpho-physiological traits of plants, yield and quality of tomato fruits (Solanum lycopersicum L.). Vegetable Crops Research Bulletin 73, 77-86.

Suryantini, S. (2016). Effect of phosphorus, organic and biological fertilizer on yield of mungbean (Vigna radiata) under two cropping patterns. Nusantara Bioscience 8(2): 273-277.

Suthamathy, N., and Seran, T.H. (2013). Residual effects of organic manure EM bokashi applied to proceeding crop of vegetable cowpea (Vigna unguiculata) on succeeding crop of radish (Raphanus sativus). Research Journal of Agriculture and Forestry Sciences, 1(1), 2-5.

Sutton, M.A., Howard, C.M., Erisman, J.W., Billen, J., Bleeker, A., Grennfelt, P., van Grinsven, H., and Grizzetti, B. (2011). The European nitrogen assessment, sources, effects and policy perspectives. Cambridge University Press, Cambridge. doi:10.1002/met.129.

Umunna, O.E., and Anselem, A. (2014). Application of organic amendments and botanical foliar sprays against bacterial disease of mungbean (Vigna radiata) in Nigeria. Greener Journal of Agricultural Sciences, 4(2), 52-57. 